\title{
Effect of various potassium and nitrogen rates and splitting methods on potato under sandy soil and arid environmental conditions
}

\author{
A. M. Al-Moshileh ${ }^{1}$, M. A. Errebhi ${ }^{2}$ and M. I. Motawei $^{1}$ \\ ${ }^{1}$ Plant Prod. and Prot. Dept, College of Agric. and Vet. Med., Qassim Univ., \\ Al-Qassim, Saudi Arabia. , P. O. Box 1482, Buraydah. \\ ${ }^{2}$ Saudi Basic Industries Corp., Industrial Complex for Research and Development, $P$. \\ O. Box 42503 Riyadh, 11551 Saudi Arabia.
}

\begin{abstract}
Potatoes require high amounts of potassium $(\mathrm{K})$ and nitrogen $(\mathrm{N})$ fertilizers for optimum growth, production and tuber quality. Farmers and farming industries under the arid conditions and sandy soils of Saudi Arabia are applying K and N fertilizers to potatoes without attention to plant requirements. Therefore, five levels of potassium fertilizer were studied on agronomic performance, tuber quality and total yield of potatoes grown on a sandy soil in the arid environment of Central Saudi Arabia. Also, the effect of four levels of nitrogen fertilizer with different splitting methods on vegetative and tuber yields of potato were studied. The field experiments were carried out during 2002 and 2003 autumn seasons at the Experimental Farm of College of Agric. \&Vet. Med., Al-Qassim University. Results reveled that increasing potassium sulfate rates resulted in a significant increase $(p \geq 0.05)$ in plant height, leaf area, chlorophyll concentration, specific gravity, $\mathrm{K}$ concentration and carbohydrate content. Marketable tuber yield was also significantly improved with increasing $\mathrm{K}$ rates. Also, the application of $300 \mathrm{~kg} \mathrm{Nha}^{-1}$ split in three equal doses gave the highest percentage of soil coverage and marketable tuber yield. Under the conditions of this experiment, it is concluded that $\mathrm{K}$ and $\mathrm{N}$ is needed by potatoes for economic yield. The recommended rate for Al-Qassim and similar regions is $450 \mathrm{~kg} \mathrm{ha}^{-1}$ potassium sulfate and $300 \mathrm{~kg} \mathrm{Nha}^{-1}$ split in three equal doses which resulted in the highest potatoes yield.
\end{abstract}

Key words: Solanum tuberosum, potassium sulphate, urea, fertilization, K element, N element, vegetative growth, yield quality, potato production.
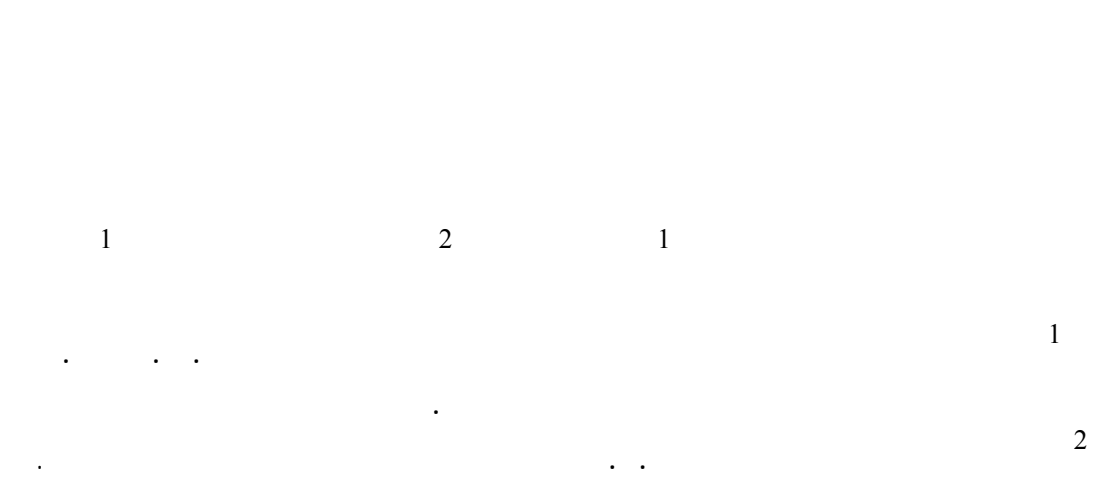

الملضص: تحتاج الططلس إلي كميت عالية من التسميد النيتروجين والبوتلسي للحصول على النمو المثالي

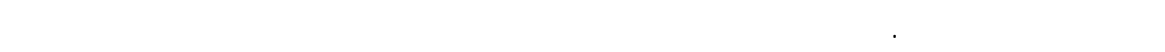

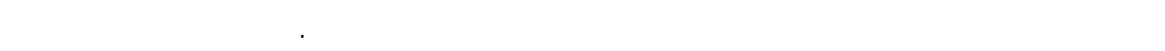

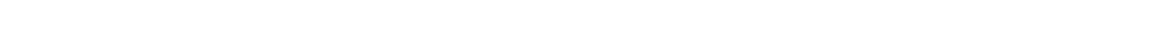

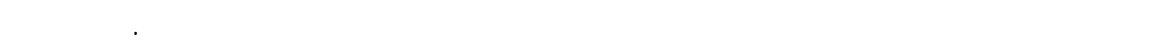

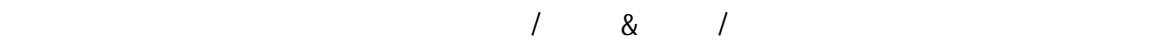

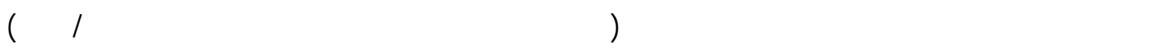

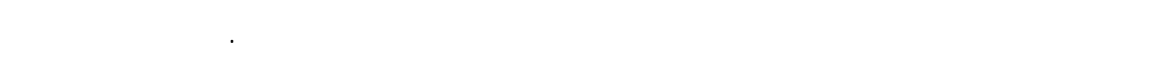

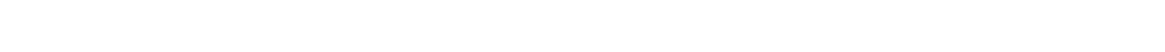

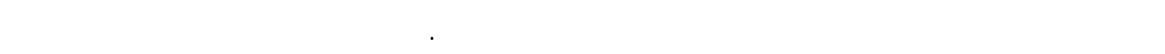

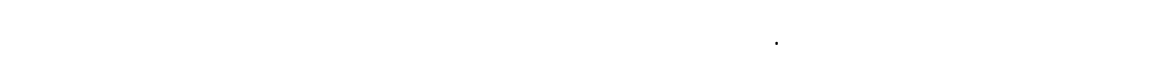




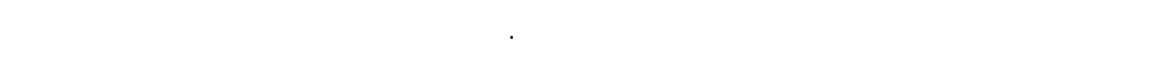

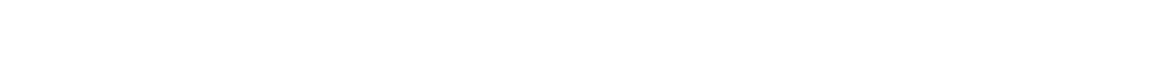

$$
\begin{aligned}
& \text { الططس وذلك تهت ظروف المنطق الجافة ذات الترب الرملية القولم. } \\
& \text { كاملت مفتلحية: كبريتات بوتلسيوه، يوريا، تسميد، عنصر النيتروجين، عنصر البوتلسيو، النمو الخضري، نوعية } \\
& \text { المحصول، إنتاج الططلس. }
\end{aligned}
$$

\section{Introduction}

The potato, Solanum tuberosum L., is the fourth most important world crop, after rice, wheat and maize (Spooner and Bamberg, 1994). It is a major source of inexpensive energy. It contains high levels of carbohydrates and significant amounts of vitamins B and $\mathrm{C}$ and other minerals. Moreover, potato is used in many industries, such as French fries, chips, starch and alcohol production (Abdel-Aal, et al., 1977).

In Saudi Arabia, potato is one of the most important crops, and AlQassim region alone accounts for about half of the annual potato production in the country (Zaag, 1991). It is mainly produced on coarse textured calcareous soils in arid land, and under center pivot irrigation systems. Average yields vary between 20 and $40 \mathrm{t} / \mathrm{ha}$ (Abdelgadir et al., 2003). The crop is judiciously fertilized with $\mathrm{N}, \mathrm{P}$ and $\mathrm{K}$ and other elements based mainly on practical experience as there is a lack of recommendations based on correlation/calibration research. Potato plants require much more potassium than many other vegetable crops. Although most soils in Saudi Arabia are rich in $\mathrm{K}$. Potassium fertilizer should be applied to sustain high yields (Zaag, 1991). An adequate supply of potassium strengthens stems to prevent lodging, increases yield and improves tuber quality (Beringer 1987; Ibrahim et al., 1987 and Omran et al., 1991). It also allows the crops to adapt to environmental stress, and promotes plant tolerance to insect infection and resistance to fungal disease. Moreover, $\mathrm{k}$ fertilizer reduced frost injury and enzymatic browning. It increased starch, total sugar, sugar, reducing sugar, protein and ascorbic acid content of tubers (Rajanne et al., 1987 and Sahota et al., 1988).

From early studies, Terman (1950) pointed out that there was a consistent decrease in the starch content of potato tubers with increase in the rate of $\mathrm{K}_{2} \mathrm{O}$ application. In a similar study Hart and Smith (1966) reported that dry matter of potatoes decreased with increasing $\mathrm{K}$ level. Excess $\mathrm{K}$ fertilizer was reported to reduce dry matter or specific gravity (Schippers, 1968; McDole, 1978 and Westermann et al., 1994a,b).

There is a general belief among farming communities in Saudi Arabia that a higher and a better quality yield of potato crop is always obtained when $\mathrm{K}$ is added in high quantities. Although the potato crop requires a heavy input of $\mathrm{K}$ for high yields (Errebhi et al., 1998), adequate levels should be established for economic yields and sustainable productivity. It is well documented that $\mathrm{K}$ affects potato quality and yield. Insufficient $\mathrm{K}$ results in reduced potato yield and smallersized tubers (McDole, 1978; Satyanarayana and Arora, 1985). Compared with the low $\mathrm{K}$ rate, the higher $\mathrm{k}$ rate increased the yield of medium (28-60mm) and over-sized $(>60 \mathrm{~mm})$ tubers by approximately 15 and $40 \%$, respectively (Tawfik, 2001). Other workers found that a significant tuber yield responses to $\mathrm{K}$ fertilization 
(Westermann et al., 1994a and Panique et al., 1997). Under the arid conditions of Wadi Ad Dawassir (latitude 20-21 N, longitude 45-46 E), Saudi Arabia, Abdelgadir et al. (2003) found that application of $215 \mathrm{~kg} \mathrm{~K}_{2} \mathrm{O} \mathrm{ha}{ }^{-1}$ was sufficient to produce an economic yield and high quality of potatoes. On the other hand, farming industries (Nadec, 2003) are applying rates higher than those reported by Abdelgader et al. (2003).

It is widely accepted that nitrogen is the most limiting nutritional factor to crop production in arid, semiarid, and desert lands. Thus, addition of $\mathrm{N}$-fertilizer to soils has become a mandatory agricultural practice in arid regions. The main source of $\mathrm{N}$ in Saudi Arabia is urea $(46 \% \mathrm{~N})$; urea is the most popular straight, solid $\mathrm{N}$ fertilizer that is used for potato production worldwide (UNIDO and IFDC, 1998). The potato crop particularly, requires high amounts of $\mathrm{N}$ for optimum yields (Errebhi et al., 1998). However, the use of $\mathrm{N}$ fertilizers is often held responsible for gaseous $\mathrm{N}$ emissions into the atmosphere (Debreczeni and Berecz, 1998; Goos and de Padua Cruz, 1999; Skiba et al., 1997) and underground water pollution (Viets, 1975; Vitosh, 1986; Adetunji, 1994; Errebhi et al., 1998). Therefore, in recent years, research and practice in arid zones of Saudi Arabia has focused on the splitting of potato $\mathrm{N}$ requirement into small doses to minimize gaseous losses. Under the arid conditions of Wadi Ad Dawassir, Abdelgadir et al. (2003) reported that $\mathrm{N}$ level of $270 \mathrm{~kg} \mathrm{~N} \mathrm{ha}^{-1}$ was sufficient to produce economic yields and high quality potatoes. The objectives of this study were to: (1) evaluate the effect of different rates of potassium sulphate, $\mathrm{K}_{2} \mathrm{SO}_{4},\left(50 \% \quad \mathrm{~K}_{2} \mathrm{O}\right)$, on agronomic performance, tuber quality and total yield of potatoes, and (2) study the effect of different rates of nitrogen fertilizer with no, two and three splits during the growing season on vegetative and tuber yield of potatoes grown in a sandy soil under arid environmental conditions.

\section{Materials and Methods}

The present study was conducted during the seasons of 2002 and 2003 at the Experimental farm of the College of Agriculture and Veterinary Medicine, King Saud University, AlQassium region (latitude 26-27 N, longitude 44-45 E, altitude $725 \mathrm{~m}$ above sea level), Kingdom of Saudi Arabia. The site of the experiment is typical arid environment with maximum and minimum mean temperature of $29^{\circ} \mathrm{C}$ and $16.0^{\circ} \mathrm{C}$, respectively. The maximum and minimum mean relative humidity are 43.3 and $18.3 \%$, respectively. Soil samples were collected prior to planting at $0-20 \mathrm{~cm}$ depth and their properties were given in Table (1). Experimental area was divided into 32 plots (15 for $\mathrm{K}$ and 27 for $\mathrm{N}$ ) separated by $1 \mathrm{~m}$ as border. Plot size was $4 \times 3$ $\mathrm{m}$. Plots were arranged in a randomized complete block design, with 3 replications. All plots received basic application of $250 \mathrm{~kg} \mathrm{P}_{2} \mathrm{O}_{5} \mathrm{ha}^{-1}$ using diammonium phosphate (46\% $\mathrm{P}_{2} \mathrm{O}_{5}$ ), applied at once before planting. Planting date was 18 September 2002 and 2003.

\section{K Treatments}

Five treatments $(0,150,300$, 450, and $600 \mathrm{~kg} \mathrm{~K}_{2} \mathrm{SO}_{4} \mathrm{ha}^{-1}$ ) were studied. Pre-sprouted tubers of cultivar Ajax were planted in rows $(75 \mathrm{~cm}$ apart) at $30 \mathrm{~cm}$ spacing between plants. All plots received $300 \mathrm{~kg} \mathrm{~N} \mathrm{ha}^{-1}$ using urea $(46 \% \mathrm{~N})$.

During the growing season, plant height, leaf area, chlorophyll and 
carbohydrate content were determined. Harvesting was carried out on 10 January 2002. Potato tubers were then graded visually into marketable $(>3.5$ $\mathrm{cm}$ in diameter) and cull $(<3.5 \mathrm{~cm}$, bruised, green or sprouted tubers). Marketable and total tuber yield were determined by weight, and only marketable tuber data is reported in this paper. Potato tuber samples were then collected from all treatments for dry matter, specific gravity, carbohydrates percent and $\mathrm{K}$ content determinations. Specific gravity was determined by the hydrometer method on a $5.0-\mathrm{kg}$ sub-sample of the marketable potatoes (Edgar, 1951).

$\mathrm{N}$ Treatments

The source of $\mathrm{N}$ was urea $(46 \% \mathrm{~N})$, and $\mathrm{N}$ levels were 0,150 , 300 , and $450 \mathrm{~kg} \mathrm{~N} \mathrm{ha}^{-1}$, arranged into the following nine treatments:

- Control (no nitrogen application).

- Application of $\mathrm{N}$ at the rate of $150 \mathrm{~kg}$ $\mathrm{N} \mathrm{ha}^{-1}$ at planting time.

- Application of $\mathrm{N}$ at the rate of $150 \mathrm{~kg}$ $\mathrm{ha}^{-1}$, split into two equal doses: planting date and 45 days after planting.
- Application of $\mathrm{N}$ at the rate of $150 \mathrm{~kg}$ $\mathrm{ha}^{-1}$, split into three equal doses: 0 , 45 , and 60 days after planting.

- Application of $\mathrm{N}$ at the rate of $300 \mathrm{~kg}$ $\mathrm{N} \mathrm{ha}^{-1}$ at planting time.

- Application of $\mathrm{N}$ at the rate of $300 \mathrm{~kg}$ $\mathrm{ha}^{-1}$, split into two equal doses: planting date and 45 days after planting.

- Application of $\mathrm{N}$ at the rate of $300 \mathrm{~kg}$ $\mathrm{ha}^{-1}$, split into three equal doses: 0 , 45 , and 60 days after planting.

- Application of $\mathrm{N}$ at the rate of $450 \mathrm{~kg}$ $\mathrm{ha}^{-1}$ at planting time.

- Application of $\mathrm{N}$ at the rate of $450 \mathrm{~kg}$ $\mathrm{ha}^{-1}$, split into two equal doses: planting date and 45 days after planting.

- Application of $\mathrm{N}$ at the rate of $450 \mathrm{~kg}$ $\mathrm{ha}^{-1}$, split into three equal doses: 0 , 45 , and 60 days after planting.

All plots received $300 \mathrm{~kg} \mathrm{~K}_{2} \mathrm{O}$ ha $^{-1}$ using $\mathrm{K}_{2} \mathrm{SO}_{4}\left(50 \% \quad \mathrm{~K}_{2} \mathrm{O}\right)$. Presprouted tubers of cultivar Ajax were planted in rows $(75 \mathrm{~cm}$ apart) at $30 \mathrm{~cm}$ spacing between plants. The growing seasons were 106 and 104 days, for the 2002 and 2003 experiments, respectively. Irrigation water samples were also collected and analyzed for $\mathrm{EC}$ and $\mathrm{pH}$ (Table 1).

Table 1. Physical and chemical proporties of soil and water used for the study.

\begin{tabular}{lcc}
\hline \multicolumn{1}{c}{ Property } & Soil & Water \\
\hline Sand $(\%)$ & 96.3 & - \\
Silt $(\%)$ & 1.8 & - \\
Clay $(\%)$ & 1.9 & - \\
Texture & sandy & - \\
$\mathrm{pH}^{1}$ & 8.4 & 7.1 \\
$\mathrm{EC}(\mathrm{mS} / \mathrm{cm})$ & - & 1.5 \\
Nutrient $(\mathrm{mg} / \mathrm{kg})^{2}$ & & \\
Total N & 15 & - \\
$\mathrm{P}$ & 16.5 & - \\
$\mathrm{K}$ & 36 & - \\
\hline
\end{tabular}

${ }^{1} \mathrm{pH}$ was measured in the extract of saturated soil paste

${ }^{2} \mathrm{P}$ was extracted using Olsen method; $\mathrm{K}$ by $1 \underline{\mathrm{N}} \mathrm{NH}_{4} \mathrm{OAc}$, $\mathrm{pH} 7$ 
During the growing season, percent soil coverage and percent tuber dry matter were determined. At the end of each season, harvesting was carried out after growth sensed and complete plants die back. Potato tubers were then graded visually into marketable $(>3.5 \mathrm{~cm}$ in diameter $)$ and cull $(<3.5 \mathrm{~cm}$, bruised, green or sprouted tubers). Marketable and total tuber yield were determined by weight, and only marketable tuber data is reported in this paper.

Statistical analysis was performed on all data using analysis of variance and for treatments comparison; least significant difference at 0.05 probability was used.

\section{Results and Discussion}

Effect of different rates of potassium application

Plant Growth Parameters: Plant height was significantly affected by $\mathrm{K}$ increasing rate. The highest plant was reached when $600 \mathrm{~kg} \mathrm{~K}_{2} \mathrm{SO}_{4} \mathrm{ha}^{-1}$ were applied (Table 2). Leaf area ranged from $1127.66 \mathrm{~cm}^{2}$ per plant at the control plants to $2603.33 \mathrm{~cm}^{2}$ per plant with application of $600 \mathrm{~kg} \mathrm{ha}^{-1} \mathrm{~K}_{2} \mathrm{SO}_{4}$. Highest leaf area was obtained with $600 \mathrm{~kg} \mathrm{~K}_{2} \mathrm{SO}_{4} \mathrm{ha}^{-1}$. The number of stems per plant, however, was not affected by K rate.

Table 2. Effect of different levels of potassium sulfate on agronomic performance of potato plant

\begin{tabular}{|c|c|c|c|c|}
\hline $\begin{array}{c}\text { Treatment } \\
\left(\mathrm{kg} \mathrm{K}_{2} \mathrm{SO}_{4} \mathrm{ha}^{-1}\right)\end{array}$ & $\begin{array}{l}\text { Plant height } \\
\text { (cm) }\end{array}$ & $\begin{array}{c}\text { Leaf area } \\
\left(\mathrm{cm}^{2} \text { plant }{ }^{-1}\right)\end{array}$ & $\begin{array}{c}\begin{array}{c}\text { Number of stems } \\
\text { (per plant) }\end{array} \\
\end{array}$ & $\begin{array}{c}\text { Chlorophyll } \\
(\%)\end{array}$ \\
\hline 0 & 28.0 & 1127.7 & 4.0 & 25.0 \\
\hline 150 & 28.7 & 1502.7 & 4.3 & 27.7 \\
\hline 300 & 39.3 & 1797.0 & 3.7 & 31.0 \\
\hline 450 & 46.3 & 2504.0 & 4.7 & 40.3 \\
\hline 600 & 47.3 & 2603.3 & 4.3 & 43.0 \\
\hline LSD (0.005) & 5.5 & 159.4 & NS & 4.5 \\
\hline
\end{tabular}

Table 3. Effect of different levels of potassium sulfate on tuber specific gravity, carbohydrates, potassium concentration and marketable yield.

\begin{tabular}{lcccc}
\hline $\begin{array}{c}\text { Treatment } \\
\text { (kg K }_{\mathbf{2}} \mathbf{S O}_{\mathbf{4}} \mathbf{h a}^{\mathbf{- 1}} \text { ) }\end{array}$ & $\begin{array}{c}\text { Specific } \\
\text { gravity }\end{array}$ & $\begin{array}{c}\text { Carbohydrates } \\
\mathbf{( \% )}\end{array}$ & $\begin{array}{c}\mathbf{K} \\
\mathbf{( \% )}\end{array}$ & $\begin{array}{c}\text { Marketable } \\
\text { tuber yield } \\
\text { (Ton ha }^{-\mathbf{1}} \text { ) }\end{array}$ \\
\hline 0 & 1.067 & 36.7 & 1.08 & 17.91 \\
150 & 1.069 & 39.7 & 1.17 & 21.53 \\
300 & 1.069 & 42.7 & 1.71 & 28.66 \\
450 & 1.084 & 50.7 & 2.09 & 31.90 \\
600 & 1.086 & 51.33 & 2.12 & 31.96 \\
LSD (0.05) & 0.003 & 1.65 & 0.21 & 2.43 \\
\hline
\end{tabular}

Tuber Yield and Quality Parameters

Tuber potassium content increased significantly with $\mathrm{K}$ rates to reach a statistical maximum of $2.09 \%$ at $\mathrm{K}$ rate of $450 \mathrm{~kg} \mathrm{~K}_{2} \mathrm{SO}_{4} \mathrm{ha}^{-1}$ (Table 3). Carbohydrate percent was increased significantly with increasing $\mathrm{K}$ rates. The highest level was reached with application of $450 \mathrm{~kg} \mathrm{~K} 2 \mathrm{SO}_{4} \mathrm{ha}^{-1}$. 
Specific gravity was also affected by increasing $\mathrm{K}$ rates. These findings are in accordance with those reported by Tawfik (2001) who found that the higher $\mathrm{k}$ rate increased the yield of medium (28-60 $\mathrm{mm})$ and over-size $(>60 \mathrm{~mm})$ tubers by approximately 15 and $40 \%$, respectively, compared with the low potassium rate. In addition, Rajanna et al. (1987) found that potassium fertilizer increased starch, total sugar and reducing sugar. On the other hand, our results did not agree with those of Davenport and Bentley (2001) and Abdelgadir et al. (2003) who found that specific gravity did not respond to $\mathrm{K}$ application.

Marketable tuber yield increased significantly $(\mathrm{p}<0.05)$ with increasing $\mathrm{K}$ rates up to $450 \mathrm{~kg} \mathrm{~K} \mathrm{KO}_{4} \mathrm{ha}^{-1}$. Higher $\mathrm{K}$ rates did not improve yield. These results agree with earlier reports by James et al. (1968), McDole (1978), Lal and Singh (1983), Rhue et al. (1986) and Chapman et al. (1992). Marketable tuber yield for $\mathrm{K}$ fertilized plots ranged from 21.53 to 31.96 tons $\mathrm{ha}^{-1}$. These yield ranges are within the 20 to $40 \mathrm{~kg} \mathrm{ha}^{-1}$ yields for Saudi Arabia; they are also comparable to yield data reported by Abdelgadir et al. (2003) for Wadi Ad Dawassir (latitude 20-21 N, longitude 45-46 E), Saudi Arabia.

Effect of different levels and splits of nitrogen fertilizer

Soil Coverage: For both seasons, and within each $\mathrm{N}$ level, the splitting of $\mathrm{N}$ doses significantly $(p \geq 0.05)$ increased leaf soil coverage (Table 4). The highest percentage of leaf soil coverage (72.48 and $67.96 \%$ ) was obtained at the application of $300 \mathrm{~kg} \mathrm{~N}$ $\mathrm{ha}^{-1}$ with split into three equal doses applied at 0,45 and 60 days after planting during the growing seasons 2002 and 2003, respectively.
Tuber Production: There is no clear and definite effect of $\mathrm{N}$ rate and splitting on tuber dry matter. Application of $\mathrm{N}$ to potatoes grown in a sandy soil under arid environmental condition significantly increased marketable tuber yield (Table 4). In both growing seasons, and without splitting the dose, increasing $\mathrm{N}$ rate resulted in a statistical tuber yield increase until the rate of $300 \mathrm{~kg} \mathrm{~N} \mathrm{ha}^{-1}$. Splitting $150 \mathrm{~kg} \mathrm{~N}$ ha-1 in three equal doses applied at 0,45 and 60 days after planting gave the highest potato tuber yield. Similar results were found for the 300 and $450 \mathrm{~kg} \mathrm{~N} \mathrm{ha}^{-1}$. However, the highest potato tuber yield was obtained at the rate of $300 \mathrm{~kg} \mathrm{~N} \mathrm{ha}^{-1}$ with split into three equal doses applied at 0,45 and 60 days after planting for the both seasons. It should noted that the application of $300 \mathrm{~kg} \mathrm{~N}$ $\mathrm{ha}^{-1}$ with three split, also, gave the highest percentage of soil coverage. Therefore, it is clear that potato production came as a result of plant vegetative growth development. Same findings were reported by Al-Moshileh and Motawei (2001) and by AlMoshileh et al. (2003). Also, data of the present study agree with previous reports of Errebhi et al. (1998) and Abdelgadir et al. (2003). However, Riley (2000) working on $\mathrm{N}$ timing effects on potatoes in Norway reported that there were no benefit from splitting the $\mathrm{N}$ application.

We believe that splitting $\mathrm{N}$ for potatoes grown in the sandy soils of arid Central Saudi Arabia is necessary for two main reasons; soils are calcareous, and $\mathrm{N}$ can easily be lost by volatilization if applied at once or even twice during the growing season; in addition, the potato crop is being irrigated every three days and, in hot months, daily, a practice that makes the potential for leaching $\mathrm{N}$ fertilizer below the rooting zone very high. In these two experiments, it is found that 
splitting $\mathrm{N}$ up to three times gave the best results. It is possible that splitting $\mathrm{N}$ to even higher number of times with smaller doses leads smaller $\mathrm{N}$ losses, and therefore, higher tuber yield.

Table 4. Effect of different levels and splits of nitrogen on percent soil coverage, percent tuber dry matter and marketable tuber yield

\begin{tabular}{lcccccc}
\hline \multirow{2}{*}{ Treatment } & \multicolumn{2}{c}{$\begin{array}{c}\text { Soil coverage } \\
(\mathbf{\% )}\end{array}$} & \multicolumn{2}{c}{$\begin{array}{c}\text { Tuber dry matter } \\
\text { (\%) }\end{array}$} & \multicolumn{2}{c}{$\begin{array}{c}\text { Marketable tuber } \\
\text { yield (ton ha } \mathbf{~}^{\mathbf{1}} \text { ) }\end{array}$} \\
\cline { 2 - 7 } & $\mathbf{2 0 0 2}$ & $\mathbf{2 0 0 3}$ & $\mathbf{2 0 0 2}$ & $\mathbf{2 0 0 3}$ & $\mathbf{2 0 0 2}$ & $\mathbf{2 0 0 3}$ \\
\hline Control & 34.5 & 32.0 & 17.0 & 14.2 & 18.5 & 17.2 \\
150 (once) & 45.2 & 45.1 & 20.2 & 16.8 & 27.8 & 22.6 \\
150-2 splits & 60.4 & 56.6 & 18.7 & 16.4 & 29.1 & 24.8 \\
150-3 splits & 71.5 & 66.9 & 18.3 & 15.7 & 33.6 & 28.9 \\
300 (once) & 47.4 & 44.5 & 19.4 & 18.3 & 30.8 & 28.3 \\
300-2 splits & 52.7 & 49.3 & 19.8 & 18.2 & 25.3 & 24.9 \\
300-3 splits & 72.5 & 68.0 & 17.5 & 16.4 & 34.5 & 39.9 \\
450 (once) & 39.4 & 40.6 & 19.5 & 18.9 & 20.6 & 17.7 \\
$450-2$ splits & 53.5 & 46.9 & 18.7 & 17.1 & 25.2 & 24.3 \\
450-3 splits & 55.9 & 58.4 & 18.8 & 17.6 & 26.2 & 23.3 \\
LSD (0.05) & 3.35 & 2.84 & 1.20 & 2.02 & 1.35 & 2.64 \\
\hline
\end{tabular}

\section{Conclusion and Recommendation}

Both plant nutritional status and tuber quality parameters responded positively to increasing $\mathrm{K}$ application rates. Marketable tuber yield was significantly affected by $\mathrm{K}$ fertilizer levels. Highest yield and other quality parameters were achieved when a rate of $450 \mathrm{~kg} \mathrm{~K}_{2} \mathrm{SO}_{4} \mathrm{ha}^{-1}$ was used. We recommend that, for Qassim and similar regions in Saudi Arabia, farmers apply potassium sulfate at the rate of $450 \mathrm{~kg} \mathrm{~K}_{2} \mathrm{SO}_{4} \mathrm{ha}^{-1}$ for optimum yield. Application of $\mathrm{N}$ improved potato tuber yield; increasing $\mathrm{N}$ rates to $300 \mathrm{~kg} \mathrm{~N} \mathrm{ha}^{-1}$ increased tuber yield. However, higher $\mathrm{N}$ rate of $450 \mathrm{~kg} \mathrm{~N}$ $\mathrm{ha}^{-1}$ resulted a drop in tuber yield. Splitting $\mathrm{N}$ rates into three doses applied equally at 0,45 , and 60 days after planting date improved yield. Results from these two experiments indicated that splitting $300 \mathrm{~kg} \mathrm{~N} \mathrm{ha}{ }^{-1}$ into three equal doses applied at 0,45 , and 60 days after planting date, gave the highest potato tuber yield. More researchers are needed to investigate the benefits of further splitting of $\mathrm{N}$ fertilizer for potatoes grown in the sandy soils under arid conditions of Central Saudi Arabia

\section{References}

Al-Moshileh, A. M. and M. I. Motawei. 2001. Effect of Light Intensity on Growth and Yield of Potato Under Central Saudi Arabia Conditions. Advances in Agricultural Research 6 (1):87-93.

Al-Moshileh, A. M., M. Z. El-Shinawy and M. I. Motawei. 2003 Effect of Shading By Date palm leaves on Growth and Yield of Potato under Different Irrigation Levels. Egypt. J. Hort. 30 (4):253-265.

Abdel-Aal, Z. S.; A. A. Khalf-Alla, M. Al-Shal, M. and M. Abd-al-Qader 1977. Vegetables Production Part 2. Dar. Al-Madboat. Al-Jadida, Publisher Alexandria, A.R.E. pp. 15-57. 
Abdeldagir, A. H., M. A. Errebhi, H. M. Al Sarhan, and M. Ibrahim. 2003. The effect of different levels of additional potassium on yield and industrial qualities of potato (Solanum tuberosum L.) in an irrigated arid region. Amer J. Potato Res. 80:219-222.

Beringer, H. 1987. Tuber growth of potato in relation to soil moisture and $\mathrm{K}$ nutrition. Abstracts $14^{\text {th }}$ Int. Bot. Congr. Dt. Bot. Ges. Berlin/FR Germany. Abstract Book.

Chapman, K. S. R., L. A. Sparrow, P. R. Hardman, D. N. Wright and J. R. A. Thorp. 1992. Potassium nutrition of Kennebec and Russet Burbank potatoes in Tasmania: Effect of soil and fertilizer potassium on yield, petiole and tuber potassium concentrations and tuber quality. Australian J. Exp. Agric. 32:521-527.

Davenport, J. R., and E. M. Bentley. 2001. Does potassium fertilizer form, source, and time of application influence potato yield and quality in Columbia basin. Amer. J. Potato Res. 78:311-318.

Edgar, A. D. 1951. Determining the specific gravity of individual potatoes. Amer. Potato J. 28:729731.

Errebhi, M., C. J. Rosen, S. C. Gupta and D. E. Birong. 1998. Potato yield response and nitrate leaching as influenced by nitrogen management. Agron. J. 90:10-15.

Hart, T. G. and O. Smith 1966. Effect of levels sources of potassium on absorption of phosphorus by potatoes. Lants. Amer. Potato J. 43: 217-235.
Ibrahim, S. A., A. I. El-Zawily, and E. A. Zayed. 1987. Effect of NPK level and ratio on growth, yield and chemical composition of potato plants grown in sandy loam soil. Egypt. J. Soil Sci. 27(2):131-144.

James, D. W., W. H. Weaver, R. L. Reeder. 1968. Soil test index of plant available potassium and the effects of cropping and fertilization in central Washington irrigated soils. Washington Agric. Exp. Station, Bull. 697.

Lal, B. and K. B. Singh. 1983. Effect of potassium on the quality of potato (Solanum tubersum L.). Agric. Sci. Digest. 3:30-33.

McDole, R. E. 1978. Potassium fertilizer tails with potatoes in coarse-textured soils in southerneastern Idaho. Amer. Potato J. 55: 161:170.

Nadec. 2003. Crop yield data: potatoes. In Annual report, 2003; Central Region, Wadi Ad Dawassir, Kingdom of Saudi Arabia.

Omran, M. S., M. Taysee, M. M. ElShinnawi and M. M. El-Sayed. 1991. Effect of macro and micronutrients application on yield and nutrients content of potatoes. Egypt. J. Soil Sci. 31 (1): 27-42.

Rajanna, K. M., K. T. Shivasankar and K.S. Krishnappa. 1987. Effect of different levels of nitrogen, phosphorus and potassium on growth, yield and quality of potato. South Indian Horticulture 35:347355.

Panique, E., K. A. Kelling, E. E. Schulte, D. E. Hero, W. R. Stevenson and R.V. James. 1997. 
Potassium rate and source effects on potato yield, quality, and disease interaction. Amer. Potato J. 74:379-398.

Rhue, R. D., D. R. Hensel, and G. Kidder. 1986. Effect of potassium fertilization on yield and leaf nutrient concentrations of potatoes grown on a sandy soil. Amer. Potato J. 63:665-681.

Sahota, T. S., H. Singh, S. S. Cheema and J. S. Grewal. 1988. Potassium nutrition of potato in India. Potash Review, No. 3, 10pp.

Satyanarayana, V., and P. N. Arora. 1985. Effect of nitrogen and potassium on yield and yield attributes of potato (var. Kufri Bahar). Indian J. Agron. 30: 292295.

Schippers, P. A. 1968. The influence of rates of nitrogen and potassium application on yield and specific gravity of four potato varieties. European Potato J. 11:23-33.

Spooner, D. M. and J. B. Bamberg. 1994. Potato genetic resources: sources of resistance and systematics. Amer. Potato J. 71:325-338.
Tawfik, A. A. 2001. Potassium and calcium nutrition improves potato production in drip-irrigated sandy soil. African Crop Sci. J. 9:147155.

Terman, G. L. 1950. Effect of rate and source of potash on yield and starch content of potatoes. Results over 20-years period. The main Agric. Exp. Sta. Orono, Main Bull. 481: 6 .

Westermann, D. T., D. W. James, T. A. Tindall and R. L. Hurst. 1994a. Nitrogen and potassium fertilization of potatoes: Yield and specific gravity. Amer. Potato J. 71:417-432.

Westermann, D. T., D. W. James, T. A. Tindall and R. L. Hurst. 1994b. Nitrogen and potassium fertilization of potatoes: Sugars and starch. Amer. Potato J. 71:432-452.

Zaag, D. E. 1991. The Potato Crop in Saudi Arabia. Saudi Potato Development Programme. Ministry of Agriculture and Water, Riyadh. Saudi Arabia.

Vitosh, M. I. 1990. Potassium recommendation. Department of agronomy. Michigan State University. USA. 